\title{
Regulating Consensual Sexual Behaviour Between Older Children: The Case Against the Current Approach under the Sexual Offences (Scotland) Act 2009
}

\author{
Dr Isla Callander ${ }^{*}$
}

\author{
A. INTRODUCTION \\ B. CURRENT APPROACH \\ (1) The law and the enforcement agenda \\ (2) Current approach in context \\ C. ISSUES WITH THE CURRENT APPROACH \\ (1) Principled objections \\ (a) Rule of law \\ (b) Conditions for liability \\ (2) Side effects \\ (3) Effectiveness \\ D. THE WAY FORWARD
}

\section{A. INTRODUCTION}

At present in Scotland, blanket criminalisation applies to all consensual sexual intercourse and oro-genital sexual activity between two older children, defined by statute as those aged thirteen to fifteen, through specific offences under section 37 of the Sexual Offences (Scotland) Act 2009. ${ }^{1}$ This provision reflects the Scottish Government's position that "the law should... make clear that society does not encourage underage sexual intercourse". ${ }^{2}$ In creating this provision, the criminal law has therefore been used as a public policy tool for signaling the

\footnotetext{
${ }^{*}$ Lecturer in Law, University of Aberdeen.

${ }^{1}$ The term "older child" is the statutory term used by the 2009 Act and is defined as a child aged thirteen to fifteen. This term is used in this article in order to be consistent with the relevant statutory terminology. The term "adolescent" is also used more generally in this article to describe the age group who are the subject matter of the article, although it is acknowledged that there are definitions of this term that are wider than its meaning in this article.

2 Scottish Government, Sexual Offences (Scotland) Bill Policy Memorandum (Scottish Parliament Corporate Body 2008) para 110.
} 
This is an Author's Accepted Manuscript that has been accepted for publication in the Edinburgh Law

Review, and is forthcoming in issue (2019) 23:2. For the Edinburgh Law Review, see

https://www.euppublishing.com/loi/ELR.

inappropriateness of sexual intercourse below the age of consent. ${ }^{3}$ This approach has been pursued in spite of the recognition that substantial numbers of older children in Scotland do, in fact, engage in consensual sexual intercourse. ${ }^{4}$ The result is that, at least theoretically, Scots law makes criminals out of significant numbers of older children involved in such activity in Scotland. However, even though the Scottish Government legislated to create specific offences explicitly criminalising older children for their consensual behaviour, this was accompanied by the intention that the provision was to be enforced discretionally and only rarely in practice. ${ }^{5}$ The indication is that older children will not actually be prosecuted unless there exists evidence of coercive or exploitative behaviour by one of the parties. ${ }^{6}$ The deliberate criminalisation of more behaviour than would likely be prosecuted in practice, and the ensuing reliance upon discretionary implementation of the provision by prosecuting authorities, is therefore the hallmark of the approach to regulating the consensual sexual behaviour of older children in Scotland.

The purpose of this article is to critically examine the current approach, in both theory and practice, to regulating the consensual sexual behaviour of older children in Scotland. The first part of this article will describe the nature of, and background to, section 37 . This will then be contextualised against the evidence of the relatively widespread occurrence of sexual intercourse amongst older children, and the very limited number of prosecutions under the provision in practice. While acknowledging that there are sound reasons to encourage older children to delay their first sexual experiences, the second part of the article will use an interdisciplinary approach to show the extent to which the current criminal law approach is genuinely problematic. This is in terms of its conformity to rule of law principles, possible adverse social consequences and potential ineffectiveness. In making this assessment the article will examine the normative principles and doctrinal legal discussions relating to criminalisation decisions, and integrate into this analysis relevant research on public health and adolescent psychological and neurological development. The final part of the article will conclude that the current Scottish approach of blanket criminalisation of older children accompanied by

\footnotetext{
${ }^{3}$ See J Chalmers "Regulating adolescent sexuality: English and Scottish approaches compared" (2011) 23(4) Child and Family Law Quarterly 450.

${ }^{4}$ See section $\mathrm{B}(2)$.

${ }^{5}$ Chalmers (n 3) at 460-461.

${ }^{6}$ See e.g. Crown Office and Procurator Fiscal Service (COPFS), Lord Advocate's Guidelines to Chief Constables: Reporting to Procurators Fiscal of Offences Alleged to have been Committed by Children: Revised Categories of Offence which Require to be Jointly Reported, rev edn (2014) at http://www.copfs.gov.uk/images/Documents/Prosecution_Policy_Guidance/Lord_Advocates_Guidelines/Lord\%20Advocate s\%20Guidelines\%20offences\%20committed\%20by\%20children.pdf.
} 
This is an Author's Accepted Manuscript that has been accepted for publication in the Edinburgh Law

Review, and is forthcoming in issue (2019) 23:2. For the Edinburgh Law Review, see https://www.euppublishing.com/loi/ELR.

discretionary enforcement is wholly inappropriate and will argue that Scots law should move towards a revised offence with an element of exploitation which the prosecution should have to prove.

Investigation of this area of law is vitally important given that the law affects a large number of older children. ${ }^{7}$ Yet, given the topic's significance, the legal response to adolescent sexuality has been acknowledged as having received insufficient attention in legal scholarship generally, ${ }^{8}$ with a particular absence of research in the Scottish context. ${ }^{9}$ Principled objections to section 37 - and the approach of blanket criminalisation accompanied by discretionary enforcement - were raised shortly after its introduction in a 2011 article by Chalmers, which compared the Scottish approach with similar, albeit more extensive, English and Welsh provisions under section 13 of the Sexual Offences Act 2003. ${ }^{10}$

This article makes a distinct contribution to scholarship in this area by reinvestigating the Scottish approach now that section 37 of the 2009 Act has been in force long enough to allow conclusions to be drawn in relation to the efficacy of the approach. This article will address a gap in the literature by evaluating for the first time both the theory and application of this law, including the rate of prosecution relative to the quantity of criminalised activity. In addition to building upon previous work on the principled objections to the current approach, this article will raise issues relating to its effectiveness and possible side effects that were hitherto unexplored in the Scottish context.

\section{B. CURRENT APPROACH}

\section{(1) The law and the enforcement agenda}

\footnotetext{
${ }^{7}$ See section $\mathrm{B}(2)$.

${ }^{8}$ See e.g. A Ashworth, "Criminal justice reform: Principles, human rights and public protection" [2004] Criminal LR 516 at 528.

${ }_{9}^{9}$ See e.g. Chalmers (n 3) at 451.

${ }^{10}$ See e.g. Chalmers (n 3). There has, in general, been more comment upon the section 13 offence in England and Wales and this literature will be drawn upon in this article.
} 
This is an Author's Accepted Manuscript that has been accepted for publication in the Edinburgh Law

Review, and is forthcoming in issue (2019) 23:2. For the Edinburgh Law Review, see

https://www.euppublishing.com/loi/ELR.

Section 37 of the 2009 Act creates two offences relating to older children who engage in penetrative sexual conduct or oro-genital contact with each other. ${ }^{11}$ It provides that where both A and B are older children, A will be guilty under section 37(1) of the offence of engaging while an older child in sexual conduct with or towards an older child if A engages in penetrative sexual conduct or oro-genital contact with B. If B engages by consent in the conduct in question, then B commits the offence under section 37(4) of engaging while an older child in consensual sexual conduct with another older child. A section 37 offence carries a maximum penalty of imprisonment for a term not exceeding ten years, and may result in the adolescent becoming subject to Sex Offender Notification Requirements. ${ }^{12}$

Prior to the inception of section 37 of the 2009 Act, sexual behaviour between older children was caught by the same miscellany of offences that would apply to an adult engaging in a "consensual" sexual act with a child. ${ }^{13}$ Section 37 therefore marked a change in approach as it contains specific offences explicitly criminalising older children. The result is that older children are subject to both more and less criminalisation than under the previous legal position. Section 37 is restricted to penile penetrative activity or oro-genital contact. In this respect the provision was regarded as progressive when it was introduced, because it actually decriminalised much conduct between older children which was formerly criminal. ${ }^{14}$ On the other hand, the new regime marked a more extensive approach to criminalisation as section 37 actually criminalised for the very first time a female older child who has sexual intercourse with a fourteen or fifteen year old boy. ${ }^{15}$

\footnotetext{
11 The 2009 Act also contains provisions for offences committed against a "young child", defined as one less than thirteen years of age (sections 18-26); and offences committed against an "older child", defined as one aged between thirteen and fifteen years of age (sections 28-36). These other offences against older children can only be committed by a person who is themselves over the age of sixteen. Furthermore, sexual conduct with an older child is not always a criminal offence. Section 39 (3) of the 2009 Act creates a proximity of age defence in relation to certain forms of sexual conduct between a person aged over sixteen and an older child where the age difference between the parties is less than two years. The defence does not apply where there is penile penetration of the vagina, anus or mouth or oro-genital contact. For commentary on the 2009 Act, see A N Brown, Sexual Offences (Scotland) Act 2009, 2nd edn (2015) 47-64.

12 Where the individual convicted has been sentenced to imprisonment, see Sexual Offences Act 2003 Schedule 3 59ZI, 59ZJ. ${ }^{13}$ A full description of the previous legal position is beyond the scope of this article, but can be found in I Callander, Improving the Statutory Regulation of Consensual Sexual Behaviour between Adolescents in Scotland (PhD thesis, University of Glasgow, 2017) ch 1.

14 J Chalmers and F Leverick (eds), The Criminal Law of Scotland Volume II, 4th edn (2016) 438. For example, if a fifteen year old boy and girl engage in sexual touching, then this consensual sexual conduct would fall short of that specified in section 37 and no offence would be committed, whereas previously the boy could have been guilty of lewd and libidinous conduct (this common law offence was abolished by section 52 of the 2009 Act).

${ }^{15}$ Under the previous law it was an offence for any person to have sexual intercourse with a girl aged between thirteen and fifteen (Criminal Law (Consolidation) (Scotland) Act 1995 section 5(3)). By contrast, it had never been an offence in itself for a female to have consensual sexual intercourse with a boy aged fourteen or older; and it was unclear whether such conduct could be charged as a form of lewd conduct at common law - see A McCall Smith and D Sheldon, Scots Criminal Law, 2nd edn (1997) 204.
} 
This is an Author's Accepted Manuscript that has been accepted for publication in the Edinburgh Law

Review, and is forthcoming in issue (2019) 23:2. For the Edinburgh Law Review, see

https://www.euppublishing.com/loi/ELR.

While sexual behaviour between older children was covered by the criminal law prior to the inception of the 2009 Act, there was little evidence of prosecutions being brought for consensual sexual activity between older children. ${ }^{16}$ With a traditional welfare-based approach to youth justice in Scotland, it was more likely that such behaviour would lead to a referral to the Children's Hearing System. ${ }^{17}$ Whether the criminal law should (continue to) apply to consensual sexual intercourse between two older children was a contentious issue when the law relating to sexual offences was codified under the 2009 Act. Both the Scottish Government and the Scottish Law Commission (SLC) agreed that acts such as kissing and sexual touching should be excluded from the criminal law. ${ }^{18}$ However, how to approach sexual intercourse between older children was a significant point of disagreement between the SLC and the Scottish Government. ${ }^{19}$

The SLC had initially intended, as set out in their discussion paper on sexual offences, that older children's sexual behaviour be covered by the criminal law in order to preserve the possibility of prosecuting children for consensual offences where there were elements of exploitation. ${ }^{20}$ However, it was subsequently concluded by the SLC that this was inappropriate, given that the effect of this would be to criminalise all older children who engage in consensual sexual activity. ${ }^{21}$ In its final Report, the SLC reversed its position and recommended that consensual sexual activity between older children should not be subject to the criminal law at all. ${ }^{22}$ Instead, the SLC recommended that there should be a new, distinctive non-offence ground of referral of a child to the Children's Hearings System - "that the child has engaged in sexual activity with another person or has been subjected to sexual activity with another person". ${ }^{23}$ In recommending this position the SLC considered that sexual intercourse between consenting older children was not sufficiently serious as to warrant criminalisation, noting that "for many teenage children sexual experimentation is regarded as a normal part of growing up"

\footnotetext{
${ }^{16}$ Between 1994 and 1999 only thirty-one children had been prosecuted for sexual offences (encompassing consensual and non-consensual activity, and activities involving both older and young children) - Scottish Law Commission, Report on Age of Criminal Responsibility (Scot Law Com No 185, 2002) Appendix D Table 7.

${ }^{17}$ It is worth noting that the passage of section 37 of the 2009 Act has not changed this approach per se - see below at section $\mathrm{B}(2)$.

18 The Scottish Government noted that such activities are "considered by most people to be a normal part of growing up for a teenager". This narrower approach was taken to avoid replicating analogous provisions in England and Wales, whereby under section 13 of the Sexual Offences Act 2003 activities such as consensual kissing and sexual touching between two older children would in theory amount to a criminal offence - Scottish Government (n 2) paras 113,140.

19 The inclusion of oro-genital contact within the section 37 provision came at a later stage, following the recommendations of the Justice Committee - see Justice Committee, Stage 1 Report on the Sexual Offences (Scotland) Bill (1st Report Session 3 (2009) SP Paper 194, Scottish Parliamentary Corporate Body 2009) paras 288-289.

${ }^{20}$ SLC, Discussion Paper on Rape and Other Sexual Offences (Scot Law Com No 131, 2006) para 5.59.

${ }^{21}$ SLC, Report on Rape and Other Sexual Offences (Scot Law Com No 209, 2007) para 4.55.

${ }^{22}$ SLC (n 21) para 4.57.

${ }^{23}$ Ibid.
} 
and it "seems quite inappropriate to criminalise consensual activities which in themselves involve no discernible social wrong". ${ }^{24}$ Presaging what was to become the approach under section 37 in Scotland, the SLC cautioned against a blanket criminalisation approach to adolescents' sexual behaviour such as that in England and Wales:

We are not impressed by the argument that such criminal liability would be theoretical only and in the vast majority of cases there would be no criminal prosecutions. Such an approach fails to take account of the possibility that older children might still be subject to investigation by the police, even if prosecution in the criminal courts is unlikely. More fundamentally, there is an important point of principle involved. If consenting sexual activity between young people is not to attract criminal liability, then the activity should not be criminal. ${ }^{25}$

The Scottish Government, however, insisted upon legislating to criminalise both older children. ${ }^{26}$ The rationale for the Scottish's Government's approach was, in essence, that section 37 was necessary in order to send a message to older children that engaging in consensual sexual intercourse is inappropriate, because of the harms that might result from that activity. ${ }^{27}$ The Policy Memorandum to the legislation was framed in terms of the need to ensure that "young people are mature and ready before they engage in sexual intercourse", with a particular focus upon the vulnerability of adolescents to the risks attendant on sexual intercourse, such as sexually transmitted infections or unwanted pregnancies. ${ }^{28}$

Yet it was clear that, as Chalmers describes, the "law was to be used to send a message, but a balance was to be struck by refraining from enforcing it". ${ }^{29}$ From the outset of the legislative process there were clear indications that while the Government legislated to this effect, the intention was that the criminal law was to be enforced discretionarily and only rarely in practice. ${ }^{30}$ The Scottish Government's deference to enforcement agencies and the resulting Lord Advocate's guidelines for police relating to section 37, which remain in force, indicate that actual prosecution should be reserved for cases involving aspects of coercive or

\footnotetext{
${ }^{24}$ SLC (n 21) para 4.52.

${ }^{25}$ SLC (n 21) para 4.55.

${ }^{26}$ Scottish Government (n 2) paras 110-122.

${ }^{27}$ See Scottish Government (n 2) para 119.

28 Ibid.

${ }^{29}$ Chalmers (n 3) at 461.

30 For commentary, see Callander (n 13) 34-37.
} 
exploitative behaviour by one of the older children. ${ }^{31}$ These state that, when considering whether to report jointly to the procurator fiscal and the Children's Reporter allegations covered by section 37 , police officers should pay attention to a series of risk indicators. ${ }^{32}$ The presence of these factors may indicate that the child may not have given "free agreement" to the activity. ${ }^{33}$ Where this is the case the matter should be jointly reported. ${ }^{34}$ While there is no exhaustive list of risk factors, they include, amongst other things: the ages of the parties; any power imbalance between the parties, for whatever reason; whether there is evidence of overt aggression, manipulation, coercion or bribery; and whether the evidence is suggestive of grooming. ${ }^{35}$

The ambit of the criminal law in Scotland is wide, with blanket criminalisation applying to older children engaging in consensual sexual intercourse or oro-genital contact with each other. Its apparent harshness might be considered mitigated or "fixed" by the discretionary approach to enforcement, as well as the existence of the Children's Hearings System. Yet as this article will discuss, criminalising more behaviour than would likely be prosecuted in practice, and subsequently relying upon discretionary implementation of the provision by prosecuting authorities, raises a number of issues. Furthermore, the existence of the Children's Hearings System should not be used as justification for allowing too extensive criminal liability, ${ }^{36}$ as involvement with this system may too have problematic consequences for a child. ${ }^{37}$

\section{(2) Current approach in context}

The current approach should be considered within the wider context of contemporary adolescent sexual behaviour in Scotland. Recent research indicates that at least a quarter of older children are likely to be engaging in oro-genital contact and sexual intercourse before the age of consent in Scotland. ${ }^{38} 31 \%$ of men and $29 \%$ of women aged sixteen to twenty-nine surveyed recently in Scotland reported first having intercourse before the age of sixteen. ${ }^{39}$ Another recent study found that $27 \%$ of fifteen year old females and $24 \%$ of fifteen year old

\footnotetext{
${ }^{31}$ COPFS (n 6).

32 Ibid.

${ }^{33}$ Ibid. Free agreement is how consent is defined in Scots law, under section 12 the 2009 Act.

${ }^{34}$ COPFS (n 6).

35 Ibid.

${ }^{36}$ G Maher, "Principles and politics in law reform: sexual offences in Scots law" (2013) Edinburgh School of Law Research Paper 2013/40 at 22.

37 For evidence of the associated problems, see e.g. L McAra and S McVie, "Youth justice? The impact of system contact on patterns of desistance from offending" (2007) 4(3) European J of Criminology 315.

${ }^{38}$ For a review of the literature see Callander (n 13) ch 2.

${ }^{39}$ E Fuller et al, Natsal-3: Key Findings from Scotland (Scottish Government 2015) 8.
} 
This is an Author's Accepted Manuscript that has been accepted for publication in the Edinburgh Law

Review, and is forthcoming in issue (2019) 23:2. For the Edinburgh Law Review, see

https://www.euppublishing.com/loi/ELR.

males in Scotland reported having experienced sexual intercourse: a figure which likely underestimates the level of adolescents engaging in sexual intercourse before the 'age of consent' given that adolescents who did not report sexual intercourse at the time of the survey, may have gone on to engage in such behaviour before turning sixteen. ${ }^{40}$ Adolescents who have sexual intercourse before the age of consent overwhelmingly do so as an older child, particularly at ages fourteen or fifteen. ${ }^{41}$ Furthermore, data suggests older children most commonly have first sexual intercourse with someone within two years of their age. ${ }^{42}$

This evidence suggests that a substantial minority of adolescents in Scotland may fall within the scope of section 37. In a sample of adolescents who reported engaging in sexual intercourse that would have amounted to an offence under the 2009 Act, ${ }^{43}$ the vast majority (86\%) were cases where the respondent reported having intercourse aged between thirteen and fifteen with another party aged between thirteen and fifteen, whereby the activity would fall within the scope of section 37. In such cases both the adolescent respondent and their partner would, in principle, be liable under section 37.

While the majority of older children in Scotland will not have engaged in oro-genital contact or sexual intercourse, at least a quarter are likely to be engaging in oro-genital contact and sexual intercourse before the age of consent, and the bulk of offences being committed are likely those under section 37 . In the most recent national census, there were over 183,000 older children in Scotland. ${ }^{44}$ This means that perhaps around 45,000 older children are liable to prosecution under this provision.

Yet the rate of prosecution is not reflective of the number of older children engaging in criminalised activity. As noted previously in this article, prior to the inception of the 2009 Act there was little evidence that older children were prosecuted for consensual sexual activity under the previous law. ${ }^{45}$ In response to a Freedom of Information (FOI) request, the Crown Office and Procurator Fiscal Service (COPFS) confirmed by email that, between the 2009 Act coming into force in December 2010 and October 2017, there were 137 charges reported to the

\footnotetext{
${ }^{40} \mathrm{C}$ Currie et al, Sexual Health of 15 Year Olds in Scotland 2: Circumstances of First Intercourse (HBSC Briefing Paper 21, Child and Adolescent Health Research Unit 2015) 2.

41 See e.g. Currie (n 40) 2; Callander (n 13) 46-47.

42 See Callander (n 13) 48-49.

${ }^{43}$ See Callander (n 13) 52-55. The sample included 1,352 adolescents who, surveyed at ages fifteen to sixteen, gave information on the age at which they first had sexual intercourse and the age of their partner. Out of these, it was found that 695 adolescent respondents reported behaviour showing that they would have committed at least one offence under the 2009 Act.

44 Scotland Census data (National Records of Scotland) at http://www.scotlandscensus.gov.uk/documents/censusresults/release1c/rel1cpopchart.pdf.

45 See footnote 16. See also Justice Committee (n 19) col 1429 (25 November 2008), where the then Lord Advocate stated that, under the prior law, there had been eight prosecutions of adolescent males in the previous three years.
} 
This is an Author's Accepted Manuscript that has been accepted for publication in the Edinburgh Law

Review, and is forthcoming in issue (2019) 23:2. For the Edinburgh Law Review, see

https://www.euppublishing.com/loi/ELR.

COPFS under section $37 .{ }^{46}$ Thus over the seven year period following section 37 coming into force, there were, on average, nineteen to twenty charges reported to the COPFS each year. The most common action taken, in relation to sixty-four of the 137 charges, was a referral to the Children's Reporter. ${ }^{47}$ Court proceedings were the second most common outcome with thirty-two of the charges resulting in that outcome. ${ }^{48}$ The Act has therefore potentially resulted in a slight increase in the number of charges being brought against older children, although the overall number remains small.

The number of charges which resulted in court proceedings also provides insight into how section 37 is being used in practice. Of the charges that had resulted in court proceedings, five charges had resulted in conviction and eleven charges had resulted in no conviction. ${ }^{49}$ This means that there are only approximately five prosecutions of a section 37 offence a year, and a rate of less than one conviction per year. Significantly, a section 37 offence was prosecuted only twice as the only sexual charge involved in the case, and twenty-five section 37 charges were prosecuted in addition to other sexual offences. ${ }^{50}$ This suggests that, whatever other offences are being additionally prosecuted, section 37 does not normally seem to be treated as warranting prosecutions in its own right.

This is also illustrated in $C v H M$ Advocate,${ }^{51}$ the only reported case to date involving a conviction for a section 37 offence. At first instance, the appellant faced nineteen charges of contraventions of different sections of the 2009 Act (including section 37), with all charges involving female complainers aged between twelve and fourteen years who were younger than the appellant at the relevant date. ${ }^{52}$ The appellant was convicted of four of these charges: sexually assaulting a child aged twelve contrary to section 20 (charge 8); intentionally causing

\footnotetext{
46 This information was obtained through a FOI request submitted to the COPFS by the author. The request was sent by email on 12 September 2017, with a written response and annexed table received over email on 9 October 2017. The data provided refers to the number of charges and not the number of persons or cases reported. Action had been taken in relation to 129 charges, with a decision still pending in relation to eight charges at the time of the response. In addition to the outcomes specified in the body of the text, thirty-one charges had resulted in no action; and two had resulted in a direct measure (i.e. an alternative to prosecution) being imposed.

${ }^{47}$ Response to FOI request. While certain acts committed by females are now criminalised for the first time, no prosecutions against females had been brought. There had, however, been twenty-six instances where adolescent females had been referred to the Children's Reporter on an offence ground, whereas previously this might not have been the case.

48 Response to FOI request. All relating to a male accused.

${ }^{49}$ Response to FOI request. A further six of these cases were ongoing at the time of the response, a further five cases had been dropped and in a further five cases a section 37 offence had not been prosecuted as a separate charge (i.e. the section 37 offence had not been separately prosecuted, but action had been taken in relation to other charges for the same accused in the same case).

${ }^{50}$ Response to FOI request. As noted previously, in five cases section 37 was not prosecuted as a separate charge. No charges were prosecuted with section 37 being an alternative charge to any sexual offence.

51 [2016] HCJAC 100, 2017 SCL 53.

52 See C v HM Advocate (n 51) at paras 1-5 per Lord Brodie for the background to the case. The original indictment had contained twenty-four charges, but five of these had been withdrawn either before the trial or at the close of the Crown case.
} 
This is an Author's Accepted Manuscript that has been accepted for publication in the Edinburgh Law

Review, and is forthcoming in issue (2019) 23:2. For the Edinburgh Law Review, see

https://www.euppublishing.com/loi/ELR.

a child aged fourteen to look at a sexual image contrary to section 6 (charge 19); sending sexual communications to a child aged twelve contrary to section 24 (charge 20); and sexual penetration of a child aged thirteen contrary to section 37 (charge 24). The issues raised in the appeal (which was refused) are outwith the scope of this article, but the circumstances of the original prosecution demonstrate that section 37 was not being prosecuted in isolation. ${ }^{53}$

The very limited number of prosecutions that have occurred in practice under section 37 stands in stark contrast to the high number of children who are potentially committing these offences. That the number of these offences being committed potentially vastly outweighs the prosecutions in practice also reflects the intended lack of an enforcement agenda behind section 37 the 2009 Act.

\section{ISSUES WITH THE CURRENT APPROACH}

As described previously, section 37 was enacted in pursuit of the Scottish Government's policy of encouraging adolescents to delay engaging in sexual intercourse. Research into adolescent psychology and neurological development shows that adolescents, as compared to adults, are more susceptible to peer influence and less able to self-regulate in order to avoid impulsive or risky behaviour. ${ }^{54}$ Furthermore, while the research shows that sexual intercourse between adolescents is not always harmful and that there can also be positive aspects to adolescent sexual behaviour, ${ }^{55}$ it indicates that it is more likely that harmful outcomes (such as unwanted pregnancy) will occur, the younger the party is. ${ }^{56}$ Perhaps most significantly, research has shown that the difference in age between an adolescent and their sexual partner is a significant

\footnotetext{
${ }^{53}$ The issue on appeal was whether there were sufficient similarities between charges 8 and 24 to allow the application of the Moorov doctrine. The appeal court found that the jury was entitled to hold that the necessary underlying similarity of time, character and circumstance was present in the evidence led in support of charges 8 and 24 for mutual corroboration to apply, and the appeal was refused - C v HM Advocate (n 51) at paras 16-20 per Lord Brodie.

${ }^{54}$ For a review of the literature, see E Shulman et al, "The dual systems model: review, reappraisal, and reaffirmation" (2016) 17 Developmental Cognitive Neuroscience 103; L Steinberg, "A social neuroscience perspective on adolescent risk-taking" (2008) 28(1) Developmental Review 78. In the context of sexual behaviour specifically, studies show, for example, that adolescents are heavily influenced by the sexual behaviour of their peers (D van de Bongardt et al, "A meta-analysis of the relations between three types of peer norms and adolescent sexual behavior" (2014) 19(3) Personality and Social Psychology Review 203) and that higher levels of impulsivity are related to riskier sexual behaviours (An L Dir et al, "A meta-analytic review of the relationship between adolescent risky sexual behavior and impulsivity across gender, age, and race" (2014) 24(7) Clinical Psychology Review 551).

${ }^{55}$ See e.g. D Wight et al, "The quality of young people's heterosexual relationships: a longitudinal analysis of characteristics shaping subjective experience" (2008) 40(4) Perspectives on Sexual and Reproductive Health 226.

56 See K Buston et al, "Young women under 16 years with experience of sexual intercourse: who becomes pregnant?" (2007) 61(3) Journal of Epidemiology and Community Health 221.
} 
This is an Author's Accepted Manuscript that has been accepted for publication in the Edinburgh Law

Review, and is forthcoming in issue (2019) 23:2. For the Edinburgh Law Review, see https://www.euppublishing.com/loi/ELR.

factor in the risk of harm - a greater age difference means a greater risk of harmful consequences. ${ }^{57}$

This article acknowledges there are clear policy reasons to support encouraging older children to delay engaging in sexual intercourse and is instead concerned with the appropriate limits of the criminal law's involvement in this sphere. While there are good policy reasons to encourage older children to delay engaging in sexual intercourse, this does not necessarily mean that blanket criminalisation is the answer or that the current criminal law is an appropriate way of achieving this policy objective.

The criminal law is a very powerful tool that should be used as a line of last resort to regulate conduct. ${ }^{58}$ If the criminal law is to be utilised, there are a number of constraints on creating and demarcating criminal offences that should be taken into account. ${ }^{59}$ These include the need for offences to conform to rule of law principles, the effectiveness of a provision in fulfilling its purpose and the possibility of adverse social consequences that might be associated with criminalisation. ${ }^{60}$ The following sections will critically assess the current approach in Scotland in terms of these issues.

\section{(1) Principled objections}

(a) Rule of law

An important principle of the rule of law is that of "fair warning", or "maximum certainty". ${ }^{61}$ Integral to this is the requirement that there should be specificity in the drafting of an offence to make it clear what conduct is prohibited. ${ }^{62}$ An established objection to the criminalisation approach taken to sexual behaviour between older children in Scotland, is that the legislation is at odds with the principle of specificity in the drafting of offences. ${ }^{63}$ This is because the substantive law has been deliberately drafted to encompass a broader range of sexual behaviour between older children than it is intended should be prosecuted in practice. ${ }^{64}$ Proper alignment of the drafting of criminal offences and their intended prosecution is important because

\footnotetext{
${ }^{57}$ For a review of the literature, see Callander (n 13) ch 5.

58 A Ashworth and J Horder, Principles of Criminal Law, 7th edn (2013) 33 (it should be noted that while there is an 8th edition of this book available, the article continues to refer to the 7 th edition on the basis that it contains more detailed discussion of the principles involved); AP Simester et al, Simester and Sullivan's Criminal Law: Theory and Doctrine, 6th edn (2016) 681.

${ }^{59}$ See Simester et al (n 58) ch 16.

${ }^{60}$ Ibid.

${ }^{61}$ Ashworth and Horder (n 58) 62; Simester et al (n 58) 678.

${ }^{62}$ Ibid.

${ }^{63}$ Chalmers (n 3) at 452.

${ }^{64}$ Ibid.
} 
individuals have a right under the rule of law to use the formal law as a guide to their conduct, ${ }^{65}$ and as a guide to the consequences of breaking it. ${ }^{66}$ Another reason that such proper alignment is an important principle is that overly inclusive offences leave too extensive scope for discretionary enforcement, with the associated danger of inconsistent treatment of offenders. ${ }^{67}$

Section 37 criminalises more conduct than would be prosecuted in practice and therefore it does not provide older children with constructive guidance as to their conduct. The issue with the blanket approach to criminalisation is not that the provisions are vague as to what conduct is unlawful. ${ }^{68}$ The issue is rather that their quality as guidance is improperly compromised to the extent that they include more conduct than is intended to be the object of their application in practice. ${ }^{69}$ This is because it is only the scope of the law as it is stated, and not as it is enforced, that can provide decisive guidance as to how an older child can avoid criminal liability. ${ }^{70}$

A blanket approach which criminalises all consensual adolescent sexual behaviour means that the only safe course of action for adolescents to avoid the risk of prosecution is to adhere strictly to the law and not engage in sexual activity at all. ${ }^{71}$ Such a prohibition is simply not realistic in the context of adolescent sexual behaviour. This issue has been at the fore in jurisdictions where the type of sexual conduct prohibited by the law is very extensive, because adolescents cannot engage in acts that would be considered universally to be part of normal adolescent behaviour without some risk of prosecution, however small. ${ }^{72}$ This is a problem given legislators may not even want adolescents to adhere strictly to the stated scope of the law. ${ }^{73}$ To prohibit any sexual activity between adolescents neglects the fact that sexual exploration can be considered to be part of adolescent development, ${ }^{74}$ and sexual activity can have positive benefits for the parties concerned. ${ }^{75}$

\footnotetext{
${ }^{65}$ V Tadros, "Crimes and security" (2008) 71(6) MLR 940 at 956, making the point that the issue is that the law must be able to provide guidance, even if, at an empirical level, it does not necessarily guide. This article will later cite evidence suggesting that adolescents do not typically regard the law as a primary guide to their sexual behavior, see section C(3).

${ }^{66}$ A Perry, "Unlucky section 13: sexual activity between children and the Sexual Offences Act 2003" (2009) 20(2) King's LJ 327 at 332 .

${ }^{67}$ Simester et al (n 58) 678.

68 Tadros (n 65) at 955.

69 Tadros (n 65) at 956.

70 Tadros (n 65) at 957; Perry (n 66) at 331.

${ }^{71}$ Perry (n 66) at 331-332.

72 Perry (n 66) at 327, 332; J R Spencer, "The Sexual Offences Act 2003: (2) - child and family offences" [2004] Criminal LR

347 at 354, noting that section 13 in England and Wales technically criminalises acts such as kissing.

73 Tadros (n 65) at 956.

${ }^{74}$ Ibid.

${ }^{75}$ See e.g. Wight et al (n 55).
} 
The Scottish approach avoids the full extent of the above criticism because it is more restrained than some other jurisdictions in the range of sexual conduct that is formally criminalised. Problems remain, however, with the blanket criminalisation approach to sexual intercourse and oro-genital contact, in terms of the quality of the guidance the law provides. With section 37 , the only way for an older child to avoid liability for their sexual behaviour with another older child is by not engaging in oro-genital contact or sexual intercourse at all. The issue, however, is that this provision has been passed despite recognition of the reality that a significant proportion of adolescents do have sexual intercourse before the age of consent. ${ }^{76}$ Significant anomalies then arise in relation to the value of the law in how it "guides" older children who do engage in such behaviour. A strict interpretation of the current law suggests that the best way for an older child to engage in sexual intercourse while also avoiding criminal liability is actually to have sexual intercourse with a person over sixteen (i.e. an adult), as that course of action would place full criminal liability on the adult, leaving the older child without liability. That the law can be interpreted in that manner is at odds with the very purpose of the general scheme of age of consent provisions, as it is the precise activity they are intended to prevent. Research indicates that if adolescents do have sexual intercourse, they are less likely to experience harmful outcomes if they do so with someone of a similar age ${ }^{77}$ - yet these are the precise circumstances where their behaviour amounts to an offence at present. That the law could be read as encouraging sexual intercourse with much older parties creates a particular difficulty in respect of females, as there are particularly strong associations between adolescent females and harmful outcomes with older partners. ${ }^{78}$ Under section 37 , a fifteen year old girl is now criminalised for having sexual intercourse with a male of the same age, which is likely to be less harmful than if she were to engage in intercourse with a much older male partner, yet it is in this latter case that she would not be criminalised. ${ }^{79}$

A second problem with the current approach under section 37 is the legislative focus on the type of sexual act rather than on the circumstances in which that act takes place. The "guidance" offered by the legislation is unhelpful in so far as it does not distinguish between circumstances where sexual intercourse is exploitative and those where it is not. ${ }^{80}$ In other

\footnotetext{
76 For such acknowledgement, see e.g. Scottish Government, National Guidance-Under-Age Sexual Activity: Meeting the Needs of Children and Young People and Identifying Child Protection Concerns (Scottish Government 2010) para 14.

77 See Callander (n 13) ch 5.

${ }^{78}$ Ibid.

79 Although her older partner would be criminalised in such circumstances.

${ }^{80}$ Tadros (n 65) at 955, making a similar point in relation to section 13 in England and Wales, in that the substantive law itself provides no indication to adolescents as to what would amount to coercive sexual behaviour.
} 
This is an Author's Accepted Manuscript that has been accepted for publication in the Edinburgh Law

Review, and is forthcoming in issue (2019) 23:2. For the Edinburgh Law Review, see

https://www.euppublishing.com/loi/ELR.

jurisdictions it has been recognised that placing all behaviour within the auspices of a single offence can contribute to adolescents' risk of negative sexual experiences, because it can blur the lines between appropriate and inappropriate behaviour. ${ }^{81}$

There is also the question of whether prosecutorial guidelines can bridge the gap between law and practice in order to allow adolescents to judge with a greater degree of certainty whether engaging in sexual intercourse is likely to lead to them being prosecuted or not. ${ }^{82}$ Unlike other jurisdictions which also have a blanket criminalisation approach, no prosecutorial guidelines are publicly available in Scotland. ${ }^{83}$ It might be considered that the Lord Advocate's guidelines to police in relation to this offence could provide adolescents with an indication of when a prosecution might be pursued, as these can be accessed online. ${ }^{84}$ However, neither these guidelines nor specific prosecutorial guidelines provide a sufficient footing on which older children can base their decisions or render the decision to prosecute "predictable" ${ }^{85}$ Such guidelines are internal guidance and therefore subject to change "at any time, without notice". ${ }^{86}$ They also lack continuity, given that the factors listed could be altered in the time between the offending behaviour in question taking place and the subsequent decision to prosecute being made. ${ }^{87}$ Individuals should also be guided by the law itself, rather than being left to second guess prosecutors' decisions, particularly as the latter are not as publicised and easily accessible as the formal law. ${ }^{88}$ These practical objections sit alongside the principled one, whereby "if the distinction between the cases where we do and do not want to prosecute can be set out in written guidelines, it can, and should, be stated in the [legislation]". 89

More generally, the approach under section 37 also explicitly normalises prosecutorial discretion as the legal response to adolescent sexual behaviour. Having an approach which relies so totally on discretion is at odds with the rule of law principle that the law itself should

\footnotetext{
${ }^{81}$ See D Perumal, "Misguided reform: regulating consensual sexual activity between adolescents in South African law from a gender perspective" (2013) 27(3) Agenda 107 at 114.

82 It should be noted once again that the issue, at this point, is about the capacity to provide guidance and its quality, rather than whether it is followed in practice.

${ }^{83}$ For example, in England see Crown Prosecution Service (CPS), Legal Guidance for Prosecutors; Rape and Sexual Offences: Chapter 2: Sexual Offences Act 2003 - Principal Offences, and Sexual Offences Act 1956-Most Commonly Charged Offences at

https://www.cps.gov.uk/legal-guidance/rape-and-sexual-offences-chapter-2-sexual-offences-act-2003-principal-offences-and ${ }^{84}$ See COPFS (n 6).

85 Perry (n 66) at 331-333.

86 Perry (n 66) at 332.

87 Ibid.

${ }^{88}$ Tadros (n 65) at 957.

${ }^{89}$ Spencer (n 72) at 354, making this point in relation to the equivalent offence in England and Wales.
} 
This is an Author's Accepted Manuscript that has been accepted for publication in the Edinburgh Law

Review, and is forthcoming in issue (2019) 23:2. For the Edinburgh Law Review, see https://www.euppublishing.com/loi/ELR.

take precedence over discretion. ${ }^{90}$ A first issue is the uncertainty inherent in relying on prosecutorial discretion not to prosecute. There is a problem with enacting a blanket criminalisation approach under a presumption, or even assertion, that it will only be enforced in certain types of cases. This is that while the stated intentions of the Government or Ministers will usually serve to guide prosecution policy, they have no force at a later stage in respect of guarding against potentially inappropriate prosecutions and cannot be raised as grounds for a defence in a case not normally within the prosecutable direction. ${ }^{91}$ This adds to the fact that, as noted earlier, the sweeping nature of a provision cannot be safely offset by the publication of prosecutorial guidance. The uncertainty in relying on prosecutors to only pursue certain types of cases is especially problematic given that, where prosecutions are pursued, guidelines do not amount to a safeguard and cannot be relied upon by an accused. ${ }^{92}$

A second issue with having a widely drawn offence accompanied by extensive prosecutorial discretion is that the law will not be applied equally to all older children who are in fact engaging in sexual intercourse. Objections therefore include the potential arbitrariness of selective reporting and enforcement. ${ }^{93}$ Selective enforcement is problematic in individual cases. Prosecutions may be disproportionate and unfair when the law is not always, or even routinely, enforced for consensual sexual behaviour. The extensive discretion associated with section 37 creates issues of consistency and transparency, ${ }^{94}$ given that different prosecutors (both reasonable) may end up making different decisions on the same set of facts.

\section{(b) Conditions for liability}

In addition to the rule of law concerns outlined in the preceding section, it can also be argued that the current approach under section 37 does not conform to appropriate principles in setting the conditions for criminal liability, in terms of both safeguards against conviction and fair labelling standards.

\footnotetext{
${ }^{90}$ See Perry (n 66) at 333 criticising analogous provisions in England and Wales for "upending the normal priority of law over discretion".

91 This has been an issue in other jurisdictions such as Western Australia - see e.g. Law Reform Commission of Western Australia (LRCWA), Community Protection (Offender Reporting) Act 2004: Discussion Paper (LRCWA Project No 101, 2011) 107. See 85-86 and 106 for case examples.

92 It is only in exceptional cases where the Crown has renounced the right to prosecute a category of cases that the accused will be able to invoke prosecutorial guidelines by way of a plea in bar of trial - see J Chalmers and F Leverick, Criminal Defences and Pleas in Bar of Trial (2006) ch 17.

${ }_{93}$ LRCWA (n 91) 86.

94 Tasmania Law Reform Institute (TLRI), Sexual Offences Against Young People: Issues Paper (TLRI No 17, 2012) para 3.4.2.
} 
This is an Author's Accepted Manuscript that has been accepted for publication in the Edinburgh Law

Review, and is forthcoming in issue (2019) 23:2. For the Edinburgh Law Review, see

https://www.euppublishing.com/loi/ELR.

The first issue is that section 37 does not contain sufficient safeguards against conviction because, while the enforcement agenda behind the provision is to prosecute in cases of exploitative behaviour, ${ }^{95}$ the prosecution need not establish the existence of exploitation in order to secure a conviction. ${ }^{96}$ In essence, the legislative approach compromises the presumption of innocence in its broadest conception. ${ }^{97}$ An obvious problem with this approach is where a prosecution is pursued in circumstances where the facts are a matter of contention. For example, an older child could be prosecuted because his behaviour is believed by the prosecutor to be exploitative. ${ }^{98}$ Yet the older child cannot contest the factual basis for the prosecutor's decision nor would they be permitted to adduce evidence at trial to refute the existence of exploitative circumstances as this would technically be irrelevant. ${ }^{99}$ Even if an older child could credibly demonstrate that there had been no exploitation on their part, they would still be liable to conviction under section $37 .{ }^{100}$

Abusive or exploitative behaviour between adolescents is clearly a legitimate concern. Where the circumstances are believed to have been exploitative, there may well be reasons why the prosecution would prosecute an age-based offence rather than, or as alternative to, an offence based upon a lack of consent. It may be that the exploitative behaviour at issue does not substantiate a rape charge. ${ }^{101}$ It is also possible that, given the evidential difficulties associated with securing a conviction for rape, it might be considered better to get a conviction for at least another sexual offence if rape might not be proven. ${ }^{102}$ Nonetheless, Chalmers has argued that:

\footnotetext{
95 This is indicated by the Lord Advocate's guidelines to police in relation to section 37, see COPFS (n 6).

96 Chalmers (n 3) at 461. See Tadros (n 65) at 954-955, discussing this point in relation to section 13 in England and Wales.

${ }_{97}$ Chalmers (n 3) at 461. Tadros (n 65) at 960, noting that the section 13 offence in England and Wales does not treat the individual adolescent "as innocent of coercion until proven guilty".

98 Chalmers (n 3) at 461.

99 Ibid.

100 Ibid.

101 This was part of the rationale for enacting the section 13 offence in England and Wales - see Home Office, Setting the Boundaries: Reforming the Law on Sex Offences, vol 1 (Home Office Communications Directorate 2000) para 3.9.8.

102 Chalmers (n 3) at 462, referring to oral evidence given by the then Lord Advocate during the passage of the 2009 Act, that indicated this to be the case - see Justice Committee (n 19) col 1429 (25 November 2008). There are however, issues surrounding whether it would be appropriate to prosecute section 37 instead of a non-consenting offence, if a lack of the consent is alleged. This point was also recognised in relation to the use of age-based offences in the evidence of the then Lord Advocate, who stated that where age-based offences are used in such circumstances, "it is very unsatisfactory for a victim to go through that process when the assertion is that she consented and her position is that she did not" (at col 1429 (25 November 2008)). It is also worth noting that the severity of the potential sentence would be affected, as the sentencing judge would have to impose the sentence on the basis that it was conviction for a consensual act - see e.g. Thomas v HM Advocate 1997 JC 35, where the appeal court held that it was wrong for the sheriff to have passed sentence on a conviction for unlawful (under-age) sexual intercourse on the basis that the complainer had not consented, the absence of consent not being an element of the charge.
} 
This is an Author's Accepted Manuscript that has been accepted for publication in the Edinburgh Law

Review, and is forthcoming in issue (2019) 23:2. For the Edinburgh Law Review, see https://www.euppublishing.com/loi/ELR.

[While there are] valid concerns which have given rise to this approach, not least the potential trauma for the complainant involved in giving evidence in a sexual offence trial... it should never be regarded as appropriate to respond to such concerns by permitting a serious criminal offence to be proven without reference to the element of moral culpability which is regarded as being the justification for prosecution, and without even the possibility of that absence of culpability being set up in the form of an affirmative defence. ${ }^{103}$

A related difficulty is that the lack of safeguards associated with the current approach may also motivate guilty pleas. ${ }^{104}$ Though pleading guilty is, in itself, not necessarily something that ought to be of issue, the concern is that such pleas might be inappropriate. For example, an older child might plead guilty in circumstances where actually they should not have been prosecuted in the first place, because they do not fall within the category of adolescents section 37 is ostensibly aimed at (i.e. those who have engaged in exploitative conduct). Although prosecutions are rare for this offence, this risk assumes increasing significance when considered against the evidence that older children are unlikely to understand fully the legal process. ${ }^{105}$ The evidence suggests that older children may be less likely to understand their rights, such as the right to silence and the longer term implications of their decisions, such as pleading guilty. ${ }^{106}$ They are also more likely to waive their rights and to accept plea agreements. ${ }^{107}$ This could be considered less of an issue as detained child suspects in Scotland now receive compulsory legal assistance, ${ }^{108}$ meaning that children who are questioned and/or charged under section 37 will not be facing this process completely alone. This measure does not, however, altogether cure the concerns over their engagement with the legal process. A child does not have to follow a lawyer's advice. Furthermore, there is also research which suggests that adolescents are less likely than adults to appreciate or trust that their lawyer's function is to be their confidential advocate. ${ }^{109}$

\footnotetext{
${ }^{103}$ Chalmers (n 3) at 461.

104 Tadros (n 65) at 958.

105 It has been found that adolescents aged fifteen and under frequently lack the basic capacities which are regarded as essential to participate in the legal process as a defendant, L Steinberg, "Juveniles on trial: Macarthur Foundation study calls competency into question" (2003) 18(3) Criminal Justice 20 at 24.

106 T Grisso et al, "Juveniles' competence to stand trial: a comparison of adolescents' and adults' capacities as trial defendants' (2003) 27(4) Law and Human Behavior 333 at 357-358; L Steinberg (n 105) at 23.

107 Grisso et al (n 106) at 357-358; L Steinberg (n 105) at 23.

${ }^{108}$ By virtue of section 33(2) of the Criminal Justice (Scotland) Act 2016 children under the age of 16 cannot consent to police questioning without a lawyer being present.

109 See M Schmidt et al, "Effectiveness of participation as a defendant: the attorney-juvenile client relationship" (2003) 21(2) Behavioral Sciences and the Law 175.
} 
A separate issue relates to the principle of fair labelling, which is concerned with ensuring that, "widely felt distinctions between kinds of offences and degrees of wrongdoing are respected and signalled by the law, and that offences are subdivided and labelled so as to represent fairly the nature and magnitude of the law-breaking". ${ }^{110}$ The issue is that using broad, age-based offences to prosecute exploitative sexual behaviour by an adolescent confounds the condemnatory value of the law. The offence description fails to meet labelling requirements as it does not adequately convey the wrong - of exploitative or coercive behaviour - that would be the reason for prosecution. ${ }^{111}$ Discussing the offence description for the analogous offence under section 13 of the Sexual Offences Act 2003 in England and Wales, Tadros has argued that:

[convicted adolescents] are condemned for sexually touching a person of their own age.... but these are terms in which we cannot plausibly condemn these people. They are either not wrong at all, or at least not wrong in a way that can justify public condemnation. $^{112}$

The issue is, therefore, that the label is wrong when exploitative behaviour is labelled for ease as consensual sexual conduct between older children. If an offence under section 37 is only ever prosecuted in circumstances where the conduct involved has in some way been exploitative, this is always going to happen. If the intention is to cover only exploitative behavior, the legislation should state this explicitly and, as noted previously, the prosecution should be required to prove this element of the crime. It might also be said that the current approach is likely to be difficult from the point of view of an older child who has been subjected to exploitation, who would see the behaviour they have been subjected to prosecuted under a label of a consensual act. ${ }^{113}$ Furthermore, where exploitative behaviour has been involved the conviction does not represent accurately the nature of the conduct to audiences who might need to be aware of this, such as prosecutors or sentencing judges, if the older child re-offends. ${ }^{114}$

\section{(2) Side effects}

\footnotetext{
${ }^{110}$ Ashworth and Horder (n 58) 77.

111 Tadros (n 65) at 960.

112 Ibid.

113 See footnote 102 and accompanying text.

${ }^{114}$ For discussion of who the audiences for labels are and why it is important to communicate accurately to these audiences see J Chalmers and F Leverick, "Fair labelling in criminal law" (2008) 71(2) MLR 217.
} 
This is an Author's Accepted Manuscript that has been accepted for publication in the Edinburgh Law

Review, and is forthcoming in issue (2019) 23:2. For the Edinburgh Law Review, see

https://www.euppublishing.com/loi/ELR.

An important factor in assessing whether, and the extent to which, conduct should be brought within the scope of the criminal law is the social impacts or side effects of criminalisation. ${ }^{115}$ Indeed, an important constraint lies in the principle of not criminalising behaviour where this would be counterproductive, in the sense that the social consequences of using the criminal law might be more detrimental than the initial conduct itself. ${ }^{116}$ In addressing this consideration, this section discusses four broad categories of potential side effects that might stem from the current approach.

The first is that creating an offence that is not intended to be enforced may reduce adolescents' respect for, and compliance with, the criminal law in general. ${ }^{117}$ Section 37 might be viewed as "lose-lose" in nature - given that it would be inherently undesirable to prosecute adolescents for their consensual sexual behaviour, but in not doing so the law may come to be viewed by adolescents as entailing "empty threats". ${ }^{118}$

A second concern is that provisions criminalising consensual sexual behaviour between older children may have an adverse knock-on effect of deterring the reporting of rape and other abusive behaviour. This could be the case in circumstances where an older child had consented to other activity, such as oro-genital contact, on the same occasion, or in circumstances where the older child had prior consensual sexual intercourse with the other older child. ${ }^{119}$ This is because the first older child would likely have to disclose all the details during the investigation of the alleged offence, including admitting any prior consensual behaviour with the other party and therefore rendering themselves liable to prosecution. Further, it is possible that the older child might be concerned that, if it could not be proven at trial that the conduct occurred without their consent, they could subsequently be prosecuted under section 37 . While this latter circumstance would be unlikely to happen in practice, the fear of prosecution could still have a deterrent impact on children who are considering whether or not to report a more serious sexual offence. Given the intractable difficulties already associated with the reporting and

\footnotetext{
115 Simester et al (n 58) 680-681; Ashworth and Horder (n 58) 33.

116 Ashworth and Horder (n 58) 34; Simester et al (n 58) 681.

117 See e.g. Maher (n 36) at 22.

118 H Keating, "When the Kissing has to Stop': Children, Sexual Behaviour, and the Criminal Law" in M Freeman (ed), Law and Childhood Studies: Current Legal Issues (2012) 264 at 276, making this point in relation to equivalent legislation in England and Wales.

119 This reasoning for not criminalising consensual sexual behaviour between adolescents was accepted by the South African Constitutional Court when striking down as unconstitutional equivalent provisions in South Africa, see Teddy Bear Clinic for Abused Children and Another v Minister of Justice and Constitutional Development and Another (Case no: CCT 12/13) [2013] ZACC 35 at para 93 per Khampepe J. For commentary, see Perumal (n 81) at 112-113.
} 
This is an Author's Accepted Manuscript that has been accepted for publication in the Edinburgh Law

Review, and is forthcoming in issue (2019) 23:2. For the Edinburgh Law Review, see

https://www.euppublishing.com/loi/ELR.

prosecution of sexual offences generally, ${ }^{120}$ it is deeply problematic that section 37 has the potential to act as a further disincentive to the reporting of rape/non-consensual conduct. This is especially when section 37 applies to children, who are a particularly vulnerable group. Section 37 may have a particularly negative effect on, and indeed indirectly discriminate against, female older children, who are significantly more likely than their male counterparts to be the victims of sexual violence. ${ }^{121}$ Simultaneously, the current approach also has the capacity to increase the likelihood of false allegations of rape/non-consensual conduct by those who did in fact freely engage in it, as a means of avoiding criminal liability. ${ }^{122}$ Section 37 may therefore be counterproductive when situated against the wider context of responding to sexual assault.

A third possible side effect of criminalisation under section 37 is that it may inadvertently increase harmful outcomes amongst adolescents who are sexually active, or becoming sexually active, by deterring them from accessing sexual health services. ${ }^{123}$ Adolescents can access sexual health services and are entitled to make decisions over health care, such as contraception. ${ }^{124}$ The issue is, therefore, more about whether the criminal law approach affects their perception of whether services are available to them rather than the reality of whether they are. There is a wealth of research evidence showing that concerns over age and confidentiality may deter adolescents from accessing medical advice and services. ${ }^{125}$ Having a provision that criminalises an older child for "consenting" to sexual intercourse which might limit their perceived access to medical services, may make it more difficult to identify children who are experiencing abusive or exploitative behaviour ${ }^{126}$ or serve to increase the likelihood of harmful sexual health outcomes if they do not perceive themselves as being able to access, for example, contraception.

\footnotetext{
${ }^{120}$ See e.g. M Burman et al, Different Systems, Similar Outcomes? Tracking Attrition in Reported Rape Cases in Eleven Countries: Scotland Country Report (2009); E Angiolini, Report of the Independent Review into the Investigation and Prosecution of Rape in London (2015).

${ }^{121}$ See e.g. C Barter et al, Partner Exploitation and Violence in Teenage Intimate Relationships (NSPCC 2009) 72, 83, finding that amongst a sample of thirteen to seventeen year old adolescents, the females were more likely to be victims, and males the perpetrators of, sexual exploitation and violence.

122 F McCallum, Sexual Offences (Scotland) Bill: Children (Research Briefing No 08/57, Scottish Parliament Information Centre 2008) 10.

${ }^{123}$ See the written submissions of both the British Medical Association and Family Planning Association to the Justice Committee during the passage of the 2009 Act, Justice Committee (n 19) paras 244-255.

124 Age of Legal Capacity (Scotland) Act 1991, section 2(4).

125 See e.g. N Stone and R Ingham, "When and why do young people in the United Kingdom first use sexual health services?" (2003) 35(3) Perspectives on Sexual and Reproductive Health 114; J Carlisle et al, "Concerns over confidentiality may deter adolescents from consulting their doctors: a qualitative exploration" (2006) 32(3) J of Medical Ethics 133.

${ }^{126}$ Similar concerns were raised in response to a Scottish Government consultation on under-age sexual activity guidance for professionals, see Scottish Government, Consultation Summary Report on Draft Guidance on Under-Age Sexual Activity: Meeting the Needs of Children and Young People and Identifying Child Protection Concerns: Scottish Government Response to Consultation (2010) para 29.
} 
This is an Author's Accepted Manuscript that has been accepted for publication in the Edinburgh Law

Review, and is forthcoming in issue (2019) 23:2. For the Edinburgh Law Review, see

https://www.euppublishing.com/loi/ELR.

A fourth possible side effect of the current approach is that it could have damaging consequences by constraining adolescents' communication with parents and other adults about sexual matters. When section 37 was enacted, there seemed little evidence in Scotland of a public desire to label adolescents who have sexual intercourse with other consenting adolescents as "criminal". ${ }^{127}$ Even if this behaviour was encompassed by the criminal law beforehand, one possible consequence of enacting strict offences explicitly criminalising adolescents for their consenting behaviour, is that it may serve to reinforce a perception of criminality amongst adults and lead to reduced inter-generational communication. ${ }^{128}$ While it may be appropriate for parents to encourage their adolescent children not to engage in sexual activity, a consequence of the current position could be that parents are less willing to discuss sexual matters with their children and those children more likely to hide their behaviour from their parents. This is problematic, given that adolescents typically want to learn about sexual matters from their parents, ${ }^{129}$ and public health research shows that higher levels of parentadolescent communication about sexual matters is associated with fewer sexual risk behaviours, such as engaging in unprotected intercourse, amongst adolescents. ${ }^{130}$ Indeed, there is increasing recognition that the use of the criminal law in this area can actually serve to increase the likelihood of risky sexual practices amongst adolescents. For example, in a decision that found a legislative scheme which criminalised all sexual behaviour between adolescents in South Africa to be unconstitutional, the Constitutional Court considered that "[r]ather than deterring early sexual intimacy, the provisions merely drive it underground, far from the guidance that might otherwise be provided by parents, guardians and other members of society". ${ }^{131}$

\section{(3) Effectiveness}

\footnotetext{
${ }^{127}$ At present, there is no information on wider public opinion regarding the criminal law being applied to consensual sexual behaviour between older children. However, part of the reason the SLC recommended decriminalising consensual sexual intercourse between thirteen to fifteen year olds was the opposition it had received during its consultation from consultees to labelling consenting older children as criminal, Maher (n 36) at 22.

${ }^{128}$ L McElroy, "Sex on the brain: adolescent psychosocial science and sanctions for risky sex" (2010) 34(4) New York University Review of Law and Social Change 708 at 751.

129 T Turnbull et al, "A review of parental involvement in sex education: the role for effective communication in British families" (2008) 67(3) Health Education Journal 182; C Tanton, "Patterns and trends in sources of information about sex among young people in Britain: evidence from three national surveys of sexual attitudes and lifestyles" (2015) 5(3) British Medical Journal Open: e007834.

130 See e.g. S Bartholomae et al, "Adolescent sexuality and parent-adolescent processes: promoting healthy teen choices" (2002) 31(6) J of Adolescent Health 264. The negative effects associated with a lack of communication, such as a higher risk of teenage pregnancy, have also been demonstrated, see K Wellings et al, "Teenage fertility and life chances" (1999) 4(3) Reviews of Reproduction 84.

${ }^{131}$ Teddy Bear Clinic for Abused Children (n 119) at para 89 per Khampepe J.
} 
This is an Author's Accepted Manuscript that has been accepted for publication in the Edinburgh Law

Review, and is forthcoming in issue (2019) 23:2. For the Edinburgh Law Review, see

https://www.euppublishing.com/loi/ELR.

A final issue relates to the effectiveness of the current approach under section 37. One reason for having a criminal law backed by sanctions is deterrence. It is, however, suggested that section 37 is unlikely to have any deterrent impact upon older children's sexual behaviour in Scotland for three reasons. The deterrent effect of the law depends, firstly, on an awareness amongst those who might engage in the behaviour involved, that they will be committing an offence. ${ }^{132}$ The first reason therefore that section 37 is unlikely to be an effective deterrent is that adolescents may not be aware of the law. ${ }^{133}$ Even if they are, adolescents might not, however, be aware of the exact severity of a section 37 offence (a maximum penalty of ten years' imprisonment) and wider legal repercussions attached to such an offence. ${ }^{134}$

Even if adolescents were better informed, there are, however, significant questions over the extent to which section 37 might influence the sexual behaviour of adolescents by acting as a deterrent. The second reason it is unlikely to be effective is because the rational actor model of individual decision-making that underpins deterrence theory does not fit well for adolescents compared to adults, given the contemporary neuroscientific and behavioural research showing the factors which influence adolescent decision-making about sexual activities in practice. ${ }^{135}$ Mid-adolescence in particular has been established as a time of heightened sensitivity to rewards and weaker cognitive control. ${ }^{136}$ These factors mean adolescents are less likely to take the law into account when making decisions about sexual behaviour, or they are more inclined to take legal risks. ${ }^{137}$ To the extent that the provision targets two adolescents of a similar age, any deterrent impact is limited because this age group is the least likely to refrain from engaging in sexual activities in response to the law. This is particularly when oro-genital contact and sexual intercourse are normative behaviours amongst this age group. ${ }^{138}$

132 See P Robinson and J Darley, "Does criminal law deter? A behavioural science investigation” (2004) 24(2) OJLS 173 at 175-178.

${ }^{133}$ While there has been no Scottish study, research has found that there is little awareness amongst adolescents in England of the details of laws relating to sexual offences such as rape, see C Withey, "Rape and sexual assault education: where is the law?" (2010) 13(4) New Criminal LR 802. See also Chalmers and Leverick (n 14) 438, noting that the particularities of section 37 are unlikely to be widely understood by the general public in Scotland.

${ }^{134}$ For example, a study in the US found that adolescents who had sexual intercourse before the age of consent with another party also under the age of consent were the group least likely to know that sex offender registration policies could apply to such activities, M Stevenson et al, 'Knowledge of juvenile sex offender registration laws predicts adolescent sexual behavior' (2013) 22(1) Journal of Child Sexual Abuse 103 at 112.

135 This argument was first made by McElroy in the context of provisions regulating adolescent sexual behaviour in the US, see McElroy (n 128) at 729-730.

136 See Shulman et al (n 54).

${ }^{137}$ McElroy (n 128) at 734-748.

${ }^{138}$ See e.g. Wight (n 55) at 230-231, finding that most adolescents who are sexually active report that they enjoy engaging in sexual intercourse. See also S Sharpe and R Thomson, All You Need is Love: The Morality of Sexual Relationships Through the Eyes of Young People (2005) 31-34, finding that the law does not necessarily "legitimise" sexual intercourse for adolescents. 
A third reason that section 37 is unlikely to be an effective deterrent is because of the relationship between its application and different aspects of punishment. It has been shown that severity of punishment does not, of itself, have a significant deterrent effect. ${ }^{139}$ As such, even if adolescents were aware of the severity of the maximum penalty attached to a section 37 offence, this is unlikely to deter adolescents from engaging in sexual intercourse. Furthermore, while certainty of punishment is more likely to have a deterrent effect in general, ${ }^{140}$ section 37 is not enforced regularly, nor has there ever been any intention that it should be. When considered in relation to the number of older children engaging in consensual sexual intercourse, the threat of prosecution and punishment is very remote, indicating that section 37 is unlikely to be of any real deterrent value. Furthermore, in addition to being limited and uncertain, the risk of punishment is also a delayed cost. This lack of immediacy between an individual's decision to offend and the imposition of punishment is recognised as a general limitation on the deterrent value of criminal sanctions. ${ }^{141}$ In addition, adolescents are more likely than adults to be predominantly influenced by their immediate circumstances; to weigh immediate rewards more heavily than future consequences; and less likely to consider the possible long term costs of their actions. ${ }^{142}$ This all indicates that the more immediate and affective rewards expected from engaging in sexual behaviour - such as intimacy, social prestige and sexual pleasure ${ }^{143}$ - are more likely to influence an adolescent's decision than potential future consequences, including the (remote) possibility of being reported to the police or prosecuted. It seems, therefore, that the legal consequences associated with section 37 are too uncertain (both in terms of likelihood or temporal proximity) to be likely to exert a meaningful deterrent impact.

The evidence does not suggest that section 37 is likely to be effective in fulfilling its purpose to the extent that this is to deter older children from engaging in sexual intercourse. It had, of course, been pointed out during the passage of section 37 that the fact that the previous law provided for the prosecution of males who had consensual sexual intercourse with underage females had not prevented a substantial proportion of adolescents in Scotland from having

\footnotetext{
139 See T Pratt et al, "The Empirical Status of Deterrence Theory: A Meta-Analysis" in F Cullen et al (eds), Taking Stock: The Status of Criminological Theory (2009) 367 at 367-395.

140 Ibid.

141 R Paternoster, "How much do we really know about criminal deterrence?" (2010) 100(3) J of Criminal Law and Criminology 765 at 821-823; Robinson and Darley (n 132) at 193-195.

${ }_{142}$ E S Scott and L Steinberg, "Adolescent development and the regulation of youth crime" (2008) 18(2) Future of Children 15 at 19.

143 See e.g. M Ott et al, "Greater expectations: adolescents' positive motivations for sex" (2006) 38(2) Perspectives on Sexual and Reproductive Health 84 at 86-88.
} 
This is an Author's Accepted Manuscript that has been accepted for publication in the Edinburgh Law

Review, and is forthcoming in issue (2019) 23:2. For the Edinburgh Law Review, see

https://www.euppublishing.com/loi/ELR.

sexual intercourse before the age of consent. ${ }^{144}$ It is perhaps for this reason that the Scottish Government avoided relying on the deterrent effect of the provision as a justification for criminalisation at that time, ${ }^{145}$ suggesting instead that the positive effect of this offence would be to provide adolescents with a prop to resist pressure to engage in sexual intercourse. ${ }^{146}$ Yet, while the Government's concern about peer pressure is a valid one, the Government did not produce any research evidence to support this argument. ${ }^{147}$ There is some support for this function in the views of young people, ${ }^{148}$ yet this use of the law as a tool to resist pressure seems to be more significant in cases where there are larger age differences. ${ }^{149}$ Furthermore, that the law might provide such a tool in some cases does not merit labelling potentially tens of thousands of older children as criminals, and opening them up to the possibility of prosecution.

While limited effectiveness of a provision may of itself not be enough to undermine its existence, it does raise the wider issue of whether the criminal law is the most appropriate way to regulate the activity in question. ${ }^{150}$ This is particularly when there are, in this sphere, other less severe methods of regulation available. The coercive approach of criminalising all consensual oro-genital sexual contact and sexual intercourse between older children can be contrasted with the more positive record of using educational approaches. There is evidence showing the value of these in encouraging adolescents to delay engaging in sexual intercourse, or at least to encourage them to engage in safer sexual practices. ${ }^{151}$

\section{THE WAY FORWARD}

While it is recognised that there are clear reasons to encourage older children to delay engaging in sexual intercourse, the current blanket criminalisation approach under section 37 does not

\footnotetext{
${ }^{144}$ See McCallum (n 122) 10. While the degree to which the age of consent has any deterrent impact on under-age sexual intercourse remains unknown, a 2014 study which collected data from fourteen to sixteen year olds across seventeen European countries, including the UK, found that the country level legal age of consent was not associated with the prevalence of "early sexual initiation' across both genders - A Spriggs Madkour et al, "Macro-level age norms for the timing of sexual initiation and adolescents" early sexual initiation in 17 European countries" (2014) 55(1) J of Adolescent Health 114 at 115, 120.

145 Scottish Government (n 2) para 119, acknowledging that it did not know the extent to which the law at that time affected sexual behaviour amongst adolescents.

146 Ibid.

${ }^{147}$ See Chalmers (n 3) for commentary.

148 See Justice Committee (n 19) para 184; R Thomson, ““An adult thing'? Young people's perspectives on the heterosexual age of consent" (2004) 7(2) Sexualities 133 at 140.

149 See Callander (n 13) 155-156.

${ }^{150}$ Simester et al (n 58) 675.

151 See e.g. UNESCO, International Technical Guidance on Sexuality Education: An Evidence-Informed Approach for Schools, Teachers and Health Educators (2009); D B Kirby et al, 'Sex and HIV education programs: their impact on sexual behaviors of young people throughout the world' (2007) 40(3) J of Adolescent Health 206.
} 
stand up to scrutiny. The law is severe, with a maximum penalty of ten years' imprisonment attached to an offence under this provision. Section 37 is also overly inclusive, capturing the behaviour of significant numbers of older children in Scotland. Even without an expectation or reality of frequent prosecution for this offence in Scotland, the wide scope of the law, the spectre of prosecution and the reliance upon the discretionary approach to enforcement is genuinely problematic and could have harmful consequences for adolescents. Indeed, the discretionary approach to enforcement does not remedy concerns about the over-inclusive nature of the provision. Rather, numerous objections render this "fix" arbitrary and inherently problematic in practice. Discretion should not be the only safeguard against criminalisation of potentially tens of thousands of older children. In addition to the rule of law and allied concerns raised in this article, the (theoretical, but still inappropriate) ambit of the criminal law risks a series of problematic social side effects.

The current approach is unlikely to deter older children from engaging in sexual intercourse. This is, in part, for the very reason that the provision is not enforced - it is a very uncertain punishment. Arguably, one way of making the provision more "effective" would be to increase enforcement. But broadening the circumstances in which prosecutions are brought would contradict guidance on enforcement and would undermine any protective intention behind the provision. The reported aspiration behind the criminalisation of consensual sexual intercourse under section 37 is "protecting [older children] from activity which could give rise to longer term adverse consequences". ${ }^{152}$ However, it could not reasonably be argued that it would be better for an older child to be prosecuted or convicted under section 37 , than to have consensual sexual intercourse with another older child. This point is even more salient when it is considered that the maximum penalty for this offence is ten years' imprisonment.

The real issue is not whether section 37 deters or not, but rather the interplay between its limited efficacy, its current weaknesses in terms of the rule of law and the potentially serious side effects of the blanket approach. Even if section 37 were to be a more effective deterrent, this would still need to be weighed against these other considerations. While the limited effectiveness of a provision may of itself not be enough to undermine its existence, the current extent of criminalisation can be challenged robustly on the basis that the approach falls foul of the rule of law and is likely to have negative side effects that may be more harmful than the prohibited conduct itself.

\footnotetext{
152 Scottish Government (n 2) para 115.
} 
This raises the question of whether there is a role for the criminal law to play at all in this context. It is submitted that the criminal law does have a role to play in regulating sexual behaviour between older children where the conduct of one of the parties is so clearly harmful that it should be considered a matter of public concern and marked out as such. In particular, the type of conduct that is considered to warrant the intervention of the criminal law is where one older child exploits or coerces another older child. This is consistent with the appropriate conception of age of consent provisions as being to protect older children against abuse and exploitation. ${ }^{153}$ While this applies particularly to protection from adults, there is a still a need to guard against exploitative sexual relationships that can exist between adolescents. ${ }^{154}$

Indeed, some common law countries are tending to move away from blanket criminalisation approaches to adolescent sexual behaviour towards more nuanced approaches which only criminalise similarly aged adolescents in circumstances of exploitation. ${ }^{155}$ With evidence showing that it is possible to enact a more targeted approach in legislation (that decriminalises but allows for prosecution where there is evidence of exploitation), it becomes harder to justify the current approach in Scotland. These approaches elsewhere should be explored further in terms of how they might provide a "blueprint" for reform in Scotland.

In conclusion, laws should not be passed unless there is an intention to enforce them. Needlessly making criminals out of potentially tens of thousands of older children who would not and should never in practice be prosecuted is, quite simply, a wholly inappropriate approach to regulating sexual behaviour between older children. A more appropriate approach would be for Scots law to move towards a revised section 37 offence which incorporates an element of exploitation which the prosecution should have to prove. Moving towards such a model would limit the scope of the criminal law in this area, provide an important safeguard against conviction (by requiring proof of exploitation) and would improve the quality of the law as guidance by focusing the substantive law on the circumstances of sexual intercourse between older children.

\footnotetext{
153 See e.g. SLC (n 20) para 5.37.

154 See e.g. Barter et al (n 121).

155 Canada is an example of a jurisdiction where consensual sexual intercourse between close in age adolescents is decriminalised unless there is evidence of an exploitative relationship (Criminal Code 1985 (Canada) sections 150.1(2) and $150.1(2.1)$ ). More recently Ireland has also incorporated such a provision into its approach to regulating adolescent sexual behaviour (section 3(8) of the Criminal Law (Sexual Offences) Act 2006, as amended by section 17 of the Criminal Law (Sexual Offences) Act 2017).
} 